(The 3rd ICBS-2013)

\title{
IDENTIFICATION OF JAVAN LANGUR (Trachypithecus auratus) IN JAVAN LANGUR CENTER (JLC) COBAN TALUN, BATU BASED ON Cytochrome-b SEQUENCE
}

\author{
Rita Rizky Rahmawati ${ }^{1}$, Emy Kusumawati ${ }^{1}$, Lulus Putri Aninda1 ${ }^{1}$ Miftahul Mushlih², \\ Abdul Gofur ${ }^{1}$, and Dwi Listyorini ${ }^{1}$ \\ ${ }^{1}$ Department of Biology, Faculty of Mathematic and Natural Science \\ State University of Malang, Jl. Semarang 5, Malang, Indonesia 65145 \\ ${ }^{2}$ Faculty of Biology, Gadjah Mada University, Yogyakarta \\ Email: tatarizky91@gmail.com; listyorini.alj@bio.um.ac.id
}

\begin{abstract}
Javan Langur (Trachypithecus auratus) is an endemic langur in Indonesia which classified as vulnerable primate. Some researches divided Javan Langur species into some subspecies, yet was not described properly. Cytochrome-b sequence from mitochondrial DNA is able to determine samples between and intraspecies as well. This study aimed to identify the Javan Langur (Trachypithecus auratus) samples named Andin (@\&) and Bobby (B\&), both are rehabilitated in Javan Langur Center (JLC). The amplification of Cytochrome-b gene from whole blood DNA with PCR technique using forward primer L151625'CTTCCATGAGGACAAATATC-3' and reverse primer Rmuc15'-GTGGAGTATAGGTATGATTGC-3'. The phylogenetic tree reconstruction based on MEGA 5 using maximum likelihood (ML) method and pairwise distance analysis with Kimura-2 parameter model resulted that Andin and Bobby are in the same group with $T$. a. auratus. Andin is in the same clade with $T$. a. auratus haplotype aaF, while Bobby in the same clade $T$. a. auratus and T. a. auratus haplotype aaC. We concluded that both of them belong to T. a. auratus subspecies.
\end{abstract}

Key words: Javan Langur (Trachypithecus auratus), Javan Langur Center (JLC), Cytochrome-b

\section{INTRODUCTION}

Javan Langur (Trachypithecus auratus) is an Indonesian endemic Langur, lives as group of 6 to 30 (13; 10). Groves (1985) divides T. auratus into two subspecies, they are T. auratus auratus and T. auratus mauritius. T. a. auratus subspecies living in East Java, Sempu Island, Bali, and Lombok, whereas T. auratus mauritius subspecies is limited in West Java and Banten. Both display difference morphological characters.

Javan Langur ( $T$. auratus) are listed as vulnerable on the IUCN Red List. Populations are decreasing due to human activities, such as habitat loss, hunting, and the illegal pet trade. NGO confesticate number of Javan Langur ( $T$. auratus) as their effort for fighting the illegal trading and domesticating of Javan Langur ( $T$. auratus). These Javan Langur ( $T$. auratus) then being rehabilitated before release to its origin habitat. One of the rehabilitation center is Javan Langur Center (JLC), an ex-situ institution which administratively is part of Javan Primate Project-The Aspinall Foundation (TAF) Indonesia Program (10). This institution located in Coban Talun Batu of East Java, focus on rehab of eastern Javan Langur. So far Javan Langur Center (JLC) only recording morphometric data from each individual of Javan Langur ( $T$. auratus) besides data of confiscation area. The release of rehabilitated Javan Langur ( $T$. auratus) requires a certified data of the origin. Since behavior and morphology characters could not give enough answer to fully resolve their evolutionary relationships or devise a stable phylogeny-based taxonomy (8). The phylogenetic data becomes 
important tool to identify each Langur.

Phylogenetic analysis can be performed using Barcoding DNA, one of it is a mitochondrial Cytochrome- $b$ (16). Cyt- $b$ has been found as a strong indicator to indentify species (14). Cyt-b has been proven to be more accurate in solving problem about the interaction of mammal phylogeny and it can differ in species level, between species and intra-species, as well $(5 ; 6 ; 4 ; 15 ; 12)$.

\section{MATERIALS AND METHODS}

Material including blood sample of 2 individu Javan Langur ( T. auratus) named Andin ( + ) and Bobby $\left(\sigma^{\top}\right)$ morphologically belongs to $T$. a. auratus. The isolation of whole DNA using Roche Isolation Mini Kitmodificated. Total DNA yield was measured using NanoDrop Spechtrophotometer (ND-2000).

Cyt-b was amplifyed using Forward primer L151625'CTTCCATGAGGACAAATATC3' and Reverse primer Rmuc15'GTGGAGTATAGGTATGATTGC3' (Muslih, 2011). Sequencing was done at Eijkman Institute for Molecular Biology, Jakarta. Peak Trace software was used to optimize the chromatogram. DNA Baser was used to get consensus sequence of $C y t-b$. The consensus sequence then confirmed using BLAST program. The phylogenetic tree reconstruction based on MEGA 5 in Maximum Likelihood (ML) method and pairwise distance analysis using Kimura-2 parameter model.

\section{RESULT AND DISCUSSION}

PCR amplification of $C y t-b$ from Andin and Bobby resulted consensus sequences of $488 \mathrm{bp}$ and $503 \mathrm{bp}$, respectively. BLAST analysis showed that the position of Cyt-b fragments of Andin and Bobby spend bases 1 to 450 and 1 to 500 , respectively, compared to Cyt-b sequences of reference species. Andin and Bobby's query value are $100 \%$ which indicates that the fragments obtained from both samples are $C y t-b$. Alignment result using Clustal $X$ software showed that $C y t-b$ sequences from both samples have a high similarity with the references from $\mathrm{NCBI}$, there are $T$. a. auratus, $T$. a. auratus haplotype $A A C$, and $T$. a. auratus haplotype $A A F$. Based on the analysis of phylogenetic trees, it is known that Andin and Bobby sharing the same group with $T$. a. auratus and separated from $T$. a. mauritius, T. germaini, T. cristatus, and T. johnii (out-group) (Figure 1). Andin is in the same clade with $T$. a. auratus haplotype $A A F$, while Bobby in the same clade with $T$. a. auratus and $T$. a. auratus haplotype AAC. The pairwise distance of the two samples show very low values $0.5 \%(<2 \%)$ which indicates that the samples included in one species (intra-species) (Figure 2). Pairwise distance values between Andin, Bobby, and T. a. auratus group are $0 \%$ to $1.7 \%$ (less than $2 \%$ ), indicated that both samples have a very close relationship with $T$. a. auratus (Vun et al., 2011). If each individual has a genetic distance (pairwise distance) based on Cyt- $b$ sequence variation less than $2 \%$, it indicates intra-species (Bradley and Baker, 2001). We concluded that both of them belong to $T$. a. auratus subspecies. This is supported by the morphological features of the two samples: Andin and Bobby have a silvery black hair colour, wide facial features, and not too clear angle facial curve (Brandon-Jones, 1995; Brandon-Jones, 2004; Kurniawan, 2012a). 


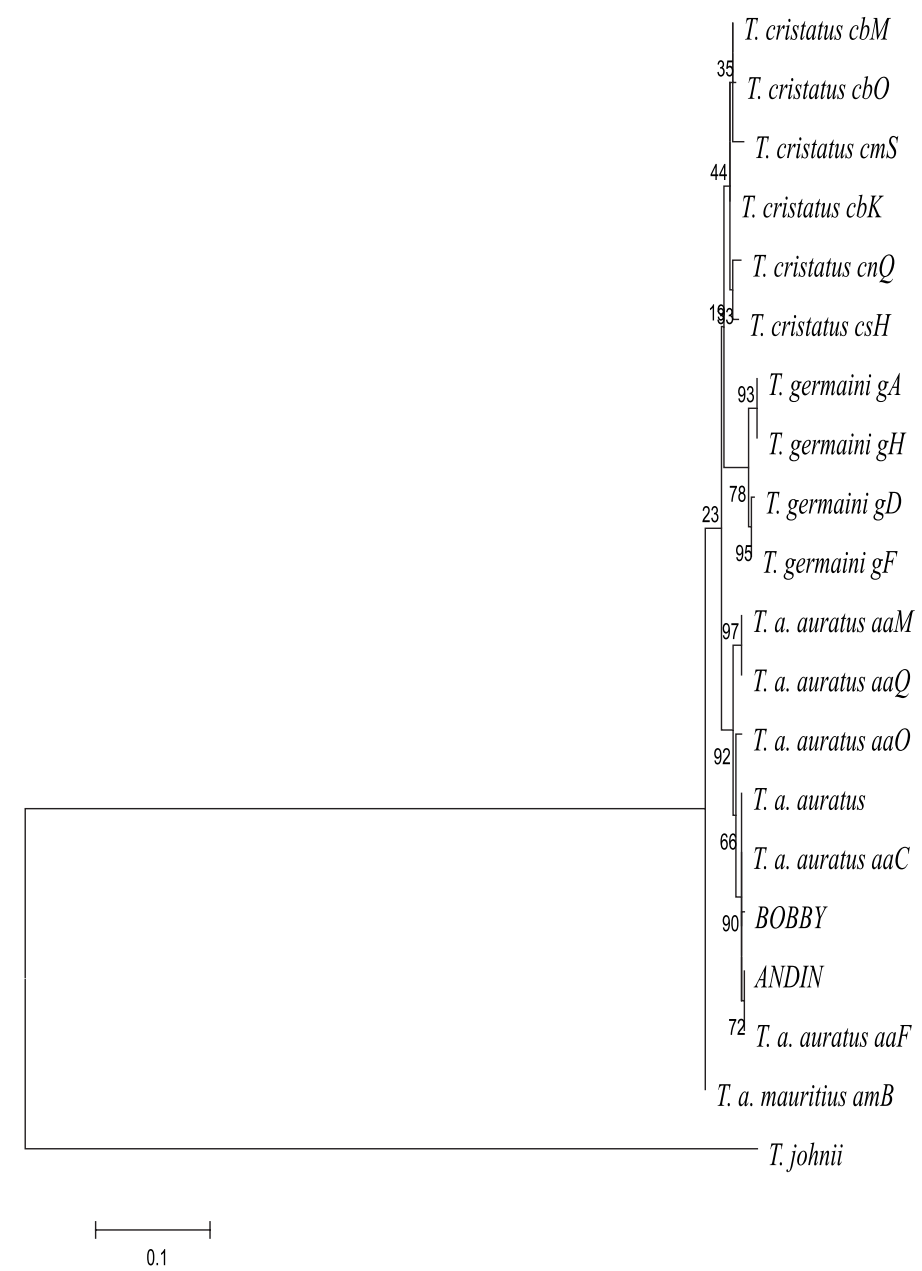

Figure 1. Cyt- $b$ Sequence Analysis in Andin, Bobby, and Other Group of Trachypithecus

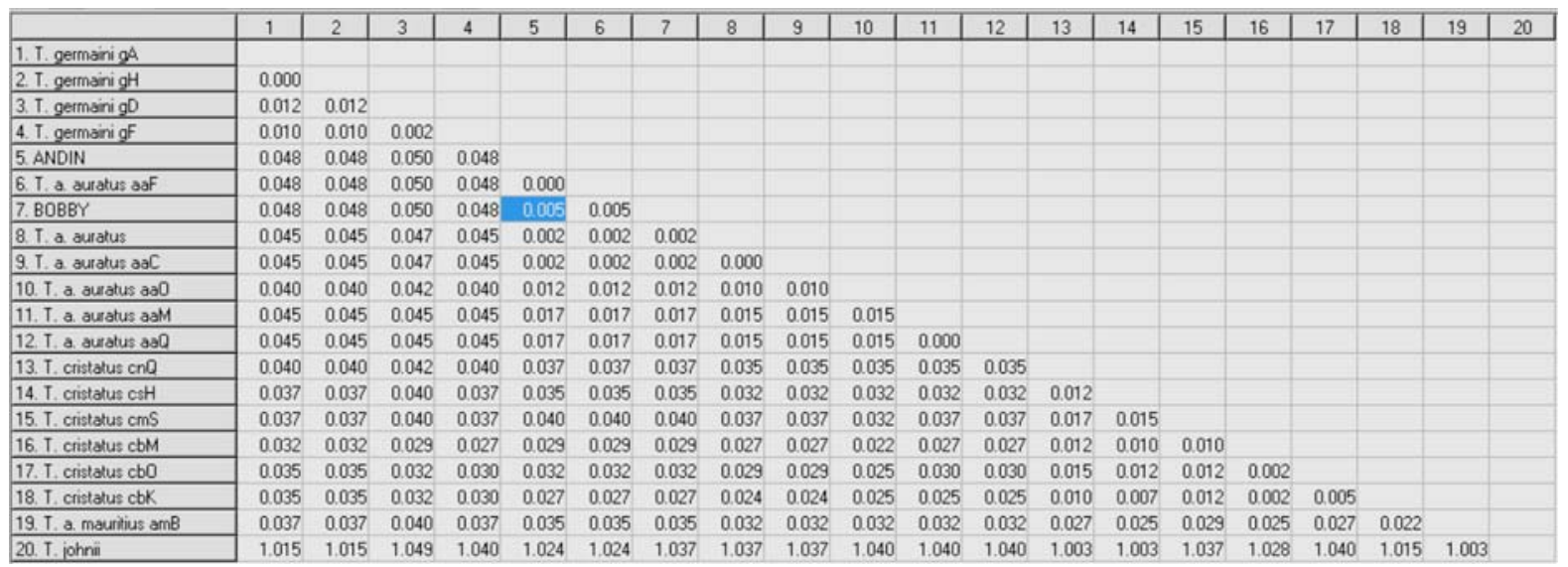

Figure 2. Pairwise Distance in Andin, Bobby, and Other Group of Trachypithecus

\section{REFERENCES}

Bradley, R.D., and R.J. Baker. 2001. A Test of the Genetic Species Concept: Cytochrome-b Sequences and Mammals. Journal of Mammalogy, 82: 960-973.

Brandon-Jones, D. 1995. A Revision of the Asian Pied Leaf-Monkeys (Mammalia: Cercopithecidae, superspesies Semnopithecus auratus), with a Description of a New Subspesies. Raffles Bulletin of Zoology, 43: 3-43. 
Brandon-Jones, D. 2004. A Taxonomic Revision of the Langurs and Leaf Monkeys (Primates: Colobinae) of South Asia. Zoo's Print Journal, 19 (8): 1552-1594.

Caine, L., G. Lima, L. Pontes, D. Abrantes, M. Pereira, and M.F. Pinheiro. 2006. Species Identification by Cytochrome-b Gene: Casework Samples. International Congress Series, 1288: 145-147.

Castresana, J. 2001. Cytochrome-b Phylogeny and the Taxonomy of Great Apes and Mammals. Molecular Biology Evolution, 18 (4): 465-471.

Farias, I.P., G. Orti, I. Sampaio, H. Schneider, and A. Meyer. 2001. The Cytochrome b Gene as a Phylogenetic Marker: the Limits of Resolution for Analyzing Relationships Among Cichlid Fishes. Molecular Evolution, 53: 89-103.

Groves, C.P., and V. Weitzel. 1985. The Nomenclature and Taxonomy of the Colobine Monkeys of Java. International Journal of Primatology, 6 (4): 399-409.

Karanth, P.K., L. Singh, R.V. Collura, and C.B. Stewart, C.B. 2008. Molecular Phylogeny and Biogeography of Langurs and Leaf Monkeys of South Asia (Primates: Colobinae). Molecular Phylogenetics and Evolution, 46: 683-694.

Kurniawan, I. 2012a. Perbedaan Fisik antara Lutung Jawa subspesies T. a. auratus dan T. a. mauritius. Malang: JLC Press.

Kurniawan, I. 2012b. Profil Program Rehabilitasi Lutung Jawa (Trachypithecus auratus). Malang: JLC Press.

Muslih, M. 2011. Kekerabatan Lutung Jawa (Trachypithecus auratus) berdasarkan Sekuen Gen Cyt-b di Javan Langur Center (JLC). Skripsi. Malang: FMIPA UM.

Nicolas, V., B. Schaeffer, A.D. Missoup, J. Kennis, M. Colyn, C. Denys, C. Tatard, C. Cruaud, C. Laredo. 2012. Assesment of Three Mitochondrial Genes (16S, Cytb, COI) for Identifying Species in the Praomyini Tribe (Rodentia: Muridae). Plos One, 7 (5): 1-11.

Nijman, V. 2000. Geographic Distribution of Ebony Leaf Monkey Trachypithecus auratus (E. Geoffroy Saint-Hilaire, 1812) (Mammalia: Primates: Cercopithecidae). Contributions to Zoology, 69 (3).

Prusak, B., T. Grzybowski, and J. Bednarek. 2005. Cytochrome b Gene (cytb) in Analysis of Anonymous Biological Traces and its Application in Veterinary Diagnostic and Animal Conservation. Animal Science Papers and Reports, 23 (4): 229-236.

Tobe, S.S., A. Kitchener, and A. Linacre. 2009. Cytochrome-b or Cytochrome C Oxidase Subunit I for Mammalian Species Identification-an Answer to the Debate. Forensic Science International: Genetic Supplement Series, 2 (1): 306-307.

Tsai, L-C., M-T. Huang, C-T. Hsiao, C-Y. A. Lin, S-J. Chen, J.C-I. Lee, and H-M. Hsieh. 2007. Species Identification of Animal Specimens by Cytochrome b Gene. Forensic Science Journal, 6 (1): 63-6.

Vun, V.F., M.C. Mahani, M. Lakim, A. Ampeng, and B.M. Md-Zain. 2011. Phylogenetic Relationships of Leaf Monkeys (Presbytis; Colobinae) based on Cytochrome-b and 12S rRNA Genes. Genetic and Molecular Research, 10 (1): 368-381. 